\title{
Research on the New Training Mode of Accounting Talents under the Background of Big Data
}

\author{
Wanyi Zhou, a, Jing Xia ${ }^{2, ~ b, ~ * ~}$ \\ ${ }^{1}$ Finance Department of Wuhan Textile University, Wuhan, Hubei 430200 \\ ${ }^{2}$ Finance Department of Wuhan Textile University, Wuhan, Hubei 430200 \\ a95252355@qq.com, b305093906@qq.com
}

Keywords: The background of big data, Accounting talents, New training mode

\begin{abstract}
In the current context of big data, accounting has been replaced by an increasing number of information systems. Under the background of big data, accounting talents in our country not only need traditional knowledge of accounting, finance and auditing, but also need to establish brand-new training path, training support and training courses, etc. which are based on the utilization of big data.
\end{abstract}

\section{Introduction}

With the coming of the Big Data era, accounting talents face new challenges which are different from the past. Accounting work is replaced by more and more information systems. Accounting staff not only need to learn traditional knowledge of accounting, finance and auditing, but also need to understand accounting information system knowledge under the background of big data (Anlin Cheng, 2012). This is because at present, the big data enterprises in China are developing rapidly and have become hot spots for economic growth. For example, Internet financial companies such as Alibaba and Jingdong all make market analysis based on big data and create huge profits. If accounting personnel do not serve the business, they will not be able to raise the corporate value and will gradually be discarded by the market. Therefore, how to cultivate the brand-new talents in the background of big data has become a major problem for the education community.

\section{New Training Mode of Accounting Talents in Our Country under the Background of Data}

How to train the ability of accountants in our country? It shows that there is an urgent need to change the current training mode based on accounting knowledge, financial management and auditing, instead, we need to establish a brand new training mode that includes knowledge of big data. The training mode includes training path, training support, training courses and so on.

\subsection{The New Training Path of Accounting Talents under the Background of Big Data}

From Figure 1, it can be seen that under the background of big data, the new mode of training accounting talents in our country mainly consists of three parts: developing an application-based teacher team, opening up interactive teaching and establishing a school-enterprise cooperation mechanism. Specifically: Firstly, develop an application-based faculty team that requires not only accounting knowledge but also big data related knowledge. The training of these knowledge can be through the school accounting teachers assigned to go abroad to learn accounting-related information technology that is the "Blue Sky Plan". After selecting teachers for foreign language and professional skills, outstanding individuals will be assigned to the relevant countries to learn various data mining techniques and to develop a big data accounting system suitable for our country. And also, we can appoint accounting teachers to enterprises to learn about the accounting information system, namely "Earth Plan”. Appointing young teachers with a certain amount of big data technology to enterprises to participate in practical activities that help enterprises to build big data accounting systems can also promote the practical ability of young teachers to teach accounting 
students and improve the overall quality of accounting staff in our country.

Secondly, promote students to learn big data knowledge through the interactive teaching between application-oriented teachers and students. The cultivation of application-oriented teacher team also needs the interaction of teachers and students, thus to realize the characteristics of teaching. This is mainly because on the one hand, under the new training mode, students are also involved in the development and practice of big data accounting systems in enterprises. They also have in-depth experience in practice, which can open up teachers' thinking through deep exchange with front-line teachers and help teachers develop new big data accounting systems. On the other hand, teachers who have acquired the most up-to-date and realistic accounting system knowledge through blue sky or earth plans can disseminate this knowledge in daily teaching and encourage students to engage in new big data accounting activities, using techniques like raw data acquisition, raw data analysis, raw data cleaning, and data mining modeling analysis to help companies find fraud and errors and address appropriate recommendations to control the corporate risk for the management, thereby enhancing corporate profits.

Finally, use school-enterprise cooperation base to improve students' knowledge of big data accounting and access to operating skills of data systems. Specifically, the establishment of a school-enterprise cooperation base needs to be integrated with the "blue sky plan" and "earth plan" of the school. That is, teachers participate in international conferences and exchanges through the Blue Sky Plan and employ experts to go to school-enterprise cooperation base for guidance with support from the school, and if possible, develop a big data accounting system suitable for Chinese enterprises and develop appropriate practical accounting talents. At the same time, through the earth plan, with the support of the school, hire domestic high-end financial accounting talent to school-enterprise cooperation base for guiding teachers, such as carrying out seminars to cultivate the vision of new accounting talents and broaden their understanding of big data accounting application, so as to lay the foundation for students to their future work and establish management accounting practice.

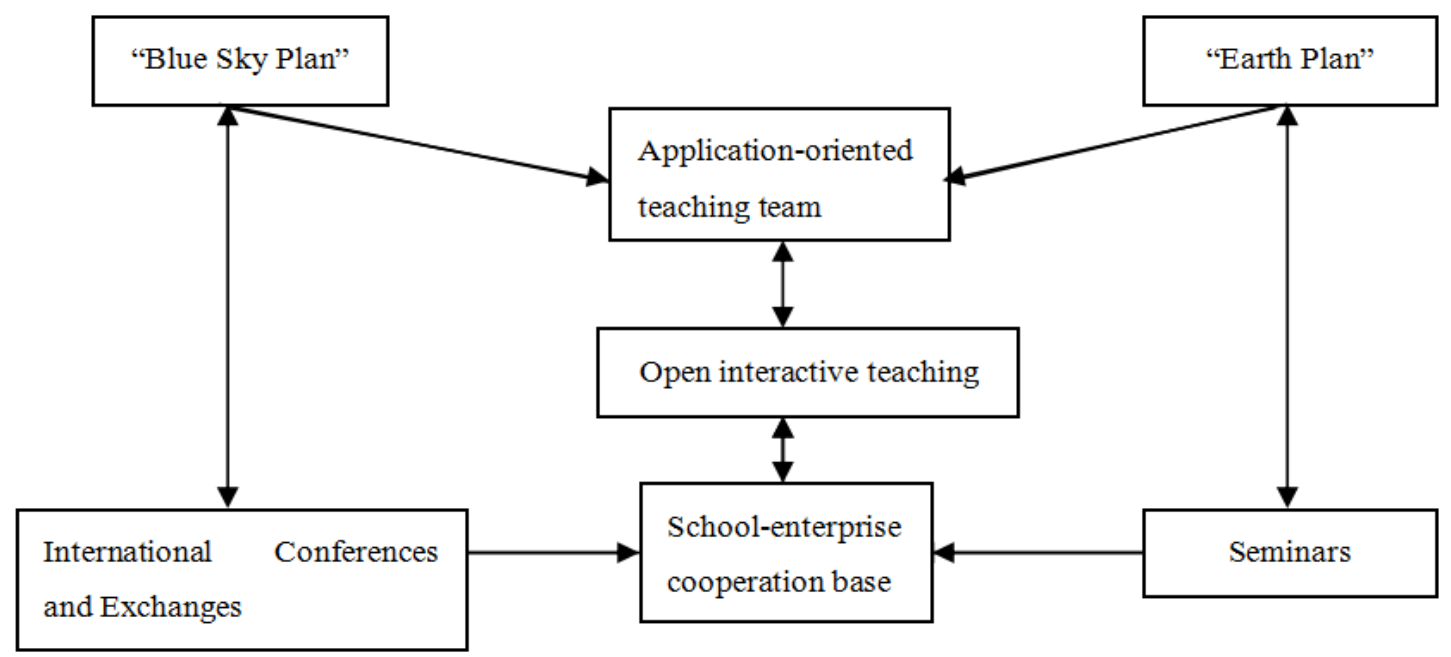

Figure 1. New Training Mode of Accounting Talents in Our Country under the Background of Data

\subsection{New Training Support of Accounting Talents in Our Country under the Background of Data}

As shown in Figure 2, under the background of big data, the new training support for accounting personnel in our country includes financial support and manpower support, both of which are indispensable. Financial support is the foundation for the school to set up a big data accounting system. Only when this system is established can the actual service for students be carried out and their innovative thinking be stimulated. Manpower support is a way to establish a school-enterprise cooperation base and cultivate new accounting talents with big data knowledge for enterprises, which comes from the traditional teaching methods of school teachers as well as lectures and training of business professionals. 
In particular: Firstly, financial support mainly includes capital investment in school laboratories, and investment in enterprise personnel training. In the school laboratory capital investment, the school states or declares provincial or national big data accounting personnel training laboratory from the Department of Education or other immediate institutions, and the school's regulatory agency puts emphasis on investment training laboratory in the original planning to promote the development of new accounting talents. In funding from relevant administrative institutions, school can contact the administrative agencies such as the Department of Commerce and the Bureau of Statistics and receive some financial support by helping them to cultivate the talents that can be used directly for practical purposes. The Department of Commerce and the Bureau of Statistics are willing to accept this kind of training because it has found that these administrative bodies spend a great deal of manpower and material resources each year to retrain social accountants in adapting to big data systems and they support colleges and universities to develop talents that can be directly used in practice. If the universities can undertake this task, these administrative units are willing to give some financial compensation. In terms of investment in enterprise personnel training, colleges and universities should cooperate with enterprises to set up a mechanism for cooperation between schools and enterprises. Enterprises should invest funds and training programs in the cooperation agencies while universities and colleges will provide excellent talents mastering in big data accounting system operating and developing for enterprises. This way not only meets the talents demand of enterprises, but also provides financial support for college training new accounting personnel.

Secondly, manpower support mainly includes the training of university teachers, external expert seminars, and enterprise special technical personnel training. Among them, the training of university teachers is the main force, which is the major training force for students to learn big data accounting system. Therefore, it is necessary to improve college accounting teachers' own big data knowledge, which can be realized through the blue sky plan and the earth plan. Then send qualified teachers to the school-enterprise cooperation mechanism, letting them lead the practice activities, which on the one hand can increase their practical experience and pass it to students better, on the other hand can improve the university teachers' ability to research and develop big data accounting system. External expert seminars can expand students' thinking, so it is necessary to regularly hire substantive experts or foreign scholars to explain the latest big data accounting system development to students, and answer students' practical problems in practice. Expert practice classes can also be arranged, requiring experts to bring students to business into practice and guide students in operating the latest big data accounting system. Special training of technical personnel of enterprises is the most important part of improving students. Schools should arrange students to participate in practice for 3-4 weeks each semester, and arrange technical talents of each enterprise as practical tutors based on the mechanism of school-industry cooperation. Practice mentors are required to supervise and develop students as they participate in the business practices and, at the end of the day, ask students to write a practice report as a course grade.

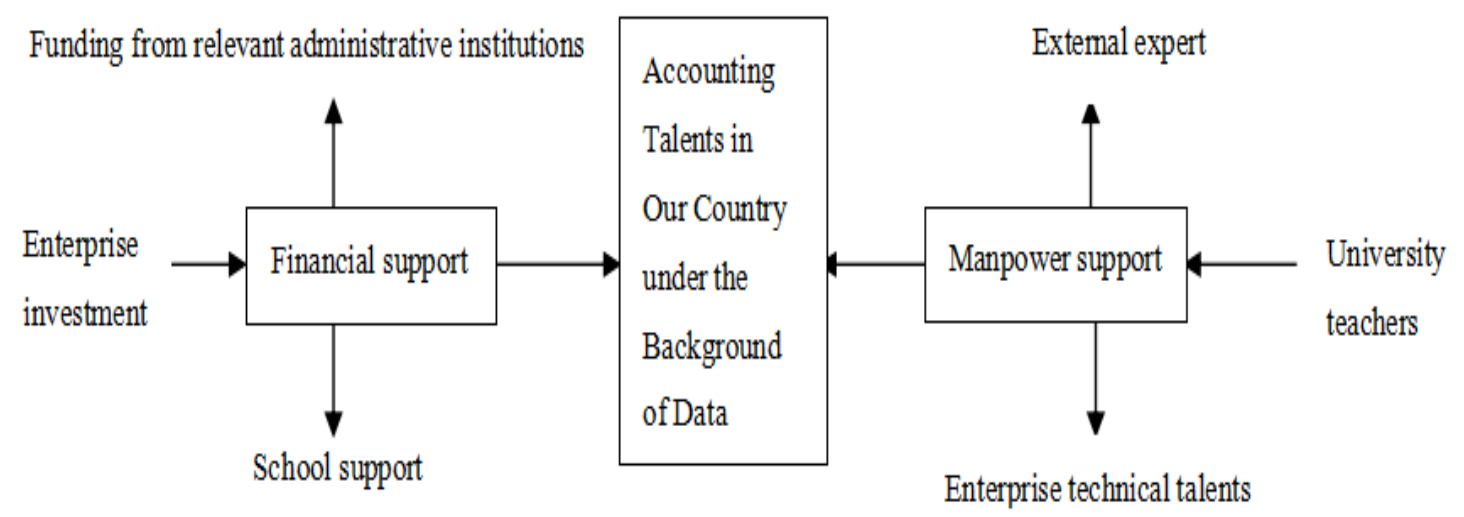

Figure 2. The New Training Support of Accounting Talents in Our Country under the Background of Data 


\subsection{New Training Courses of Accounting Talents in Our Country under the Background of Data}

As shown in Figure 3, under the background of big data, the new training courses for accounting talents in our country consists of two parts: the traditional curriculum and the innovative curriculum. The traditional courses are mainly primary, intermediate and advanced financial accounting courses, financial management courses and auditing courses. The purpose of accounting courses is to enable students to understand the accounting standards and accounting methods. Although accounting talents in the context of big data are mainly applied to big data accounting systems, the system is also based on accounting standards, so without further studying accounting standard, students can not understand the economic nature of the information system processing and it is also difficult for them to make management recommendations for management. Financial management courses are the foundation for data analysis, which take a variety of financial analysis methods to help managers identify risks and make comments. Therefore, setting this course is a necessary part of cultivating new management talents and requires the knowledge of the old teachers who have practical experience. The audit course is designed to help accountants understand the causes of fraud and error so that in the initial analysis accountants can help enterpeises detect the risk of fraud, thereby minimizing the risk and preventing any further expansion of fraud.

Innovative courses include data analysis courses, data mining courses and information system operation courses. Among them, the data analysis course mainly introduces the knowledge of regression analysis, that is, accounting staff learn the use of regression analysis to understand related factors of business, finance or production, and thus propose the corresponding improvement strategy; typical case analysis, that is, accounting personnel learn to use a typical correlation case study to find how other companies in the industry to deal with the situation, which will help business management solve the current problems; knowledge of demand analysis, that is, accounting personnel learn to use demand analysis, which can help companies find out the shortage of raw materials, the market needs of a product, whether the research and development of a product can meet the business requirements and other issues. Data mining courses mainly teach knowledge of clustering mining modeling and analysis, that is, teach accounting staff how to classify financial and non-financial data so as to discover the different data in this type of data. Outlier data mining modeling and analysis is teaching accounting staff how to analyze these discrete data as a specific problem in order to become a breakthrough for the management to develop their business. The information system operation course is mainly based on the school-enterprise cooperation base, in which teachers participate in international conferences and exchanges through the Blue Sky Plan and employ experts with support from the school to guide teachers to develop a big data accounting system suitable for Chinese enterprises and train corresponding practical accounting talents. At the same time, through the earth program, hire domestic top financial accounting talent to school cooperation base with the support of the school to guide teachers and broaden their understanding of big data accounting application.

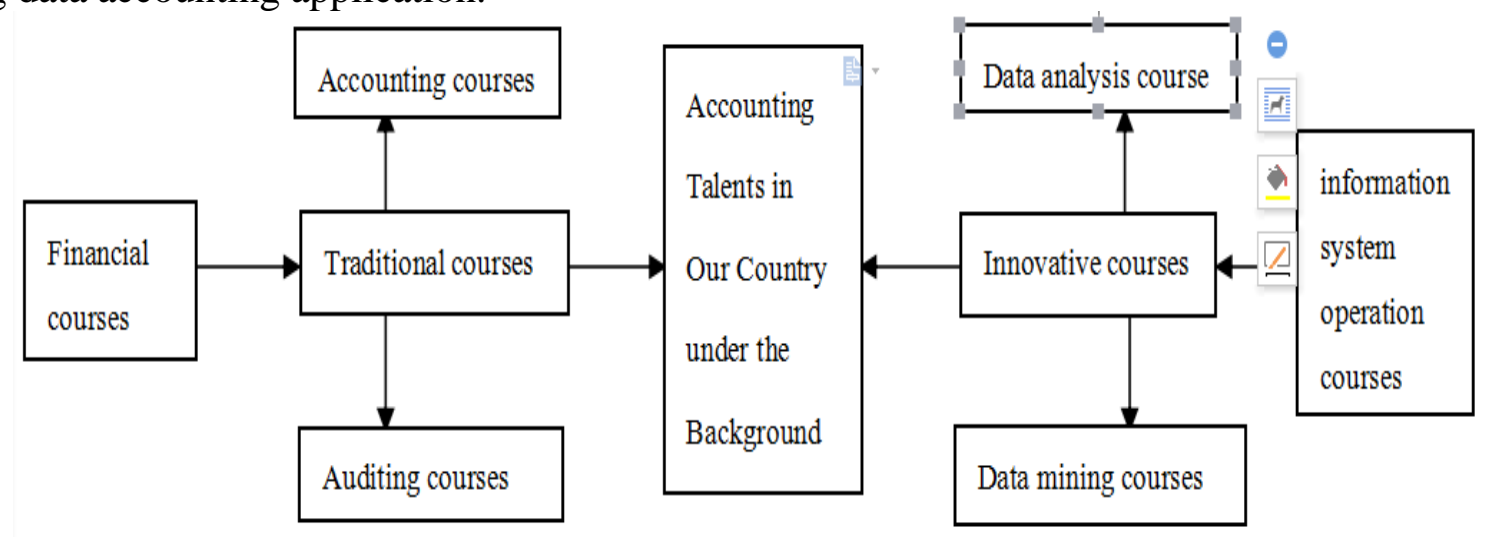

Figure 3. New Training Courses of Accounting Talents in Our Country under the Background of Data 


\section{Conclusion}

In the current urgent need to train accounting talents under the background of big data in China, we believe that universities should carry out big data accounting training project. Specifically, under the background of big data, accounting talents in our country not only need traditional knowledge of accounting, finance and auditing, but also need to establish brand-new training path, training support and training courses, etc. which require knowledge of big data.

\section{References}

[1] Cheng Anlin. Research on training mode of excellent accounting talents [J]. Finance and Accounting Monthly, 2011(11): 91-93.

[2] Li Shuang, Tan Wenhao. The training of accounting talents based on accounting practice teaching: Discussion on the construction of accounting discipline [J]. Communication of Finance and Accounting, 2011(11):154-157.

[3] Teng Xiaomei. Research on the connotation of excellent accounting talents in applied undergraduate colleges [J]. Communication of Finance and Accounting, 2014(9): 121-125.

[4] Tong Chengsheng, Xu Sulan, Li Kouqing, Liang Shuping. Research on training mode of accounting talents in Chinese enterprises [J]. The Accounting Research, 2014(9): 13-20.

[5] Zhao Caixia, Wu Du, Lei Guoqiong. The thought and method of the training of accounting information management talents in big data era [J]. Chinese Management Information. 2016(3):34-36. 